SUSTAINABLE FORESTRY

COLLECTION 65-66, 2012
ODRŽIVO ŠUMARSTVO

ZBORNIK RADOVA 65-66, 2012

UDK $630 * 18(497.11)(23.045$ Pešter $)=111$

Original scientific paper

\title{
BEECH AND FIR FOREST RESOURCES IN THE PEŠTER PLAIN AREA
}

\author{
Mihailo RATKNIĆ ${ }^{1}$, Ljubinko RAKONJAC ${ }^{1}$, \\ Tatjana RATKNIĆ ${ }^{2}$, Sonja BRAUNOVIĆ ${ }^{1}$
}

\begin{abstract}
According to EUNIS classification, the analysed stands belong to a mixed beech-fir forest type (G4.61). The soils are eutric cambisol, eutric rankers, distric cambisol and luvisol. 65 plants were identified, out of which 6 tree species, 9 shrub species and 50 ground flora species. The ecological indices have the following averages values: humidity from 2.90 to 3.00, soil chemical reaction from 2.71 to 3.15 , nutrient matter from 2.55 to 2.83 , light from 2.28 to 2.60 and temperature from 2.56 to 3.07. Out of the total number of recorded plants, 29, that is, $46.0 \%$ are medicinal, namely; 4 species come under healing class one, 2 come under healing class two, 11 come under healing class three, 6 come under healing class four and 6 come under healing class five. The following fruit tree species were identified: Vaccinium myrtillis, Crataegus monogyna, Fragaria vesca, Sorbus aucuparia, Lonicera nigra, Rubus hirtus, Sorbus austriacus. 24 melliferous plants were recorded in beech and fir forests, out of which 6 woody, 6 shrub and 10 herbaceous plants. The highest number of melliferous plants blossom in May. The beech and fir forest was recorded on 464.09 hectares. The total volume is $161,015 \mathrm{~m}^{3}$. The trees with a diameter lower than $30 \mathrm{~cm}$ account for $51.5 \%$.
\end{abstract}

Key terms: beech and fir forests, G4.61, sustainable use, natural resources

\section{RESURSI ŠUME BUKVE I JELE NA PODRUČJU PEŠTERSKE VISORAVNI}

Извод: Pо EUNIS klasifikaciji analizirane sastojine pripadaju mešovitim bukovojelovim šumama (G4.61). Zemljišta su eutrični kambisoli, eutrični rankeri, distrični

\footnotetext{
${ }^{1}$ Institute of Forestry, 3 Kneza Višeslava Street, Belgrade, Serbia

${ }^{2}$ Faculty of Applied Ecology 'Futura', Belgrade, Serbia
} 
kambisoli i luvisoli. Konstatovano je 65 biljaka, od čega 6 vrsta drveća, 9 vrsta žbunova $i$ 50 vrsta prizemne flore. Ekološki indesi za vlažnost imaju prosečnu vrednost od 2.90 do 3.00 , za hemijsku reakciju zemljišta od 2.71 do 3.15, za hranljive materije od 2.55 do 2.83, za svetlost od 2.28 do 2.60 i za temperaturu od 2.56 do 3.07. Od ukupno registrovanih biljaka 29 je lekovito, odnosno 46.0\% $i$ to: 4 pripadaju prvoj, 2 drugoj, 11 trećoj, 6 četvrtoj $i \quad 6$ vrsta petoj kategoriji lekovitosti. Konstatovane su sledeće vrste voćkarica: Vaccinium myrtillis, Crataegus monogyna, Fragaria vesca, Sorbus aucuparia, Lonicera nigra, Rubus hirtus, Sorbus austriacus. U šumama bukve i jele konstatovano je 24 medonosnih vrsta, od čega 8 drvenastih, 6 žbunastih i 10 zeljastih. Broj medonosnih biljaka u cvetu je najveći tokom maja. Šuma bukve i jele konstatovana je na 464.09 hektara. Ukupna zapremina je $161015 \mathrm{~m}^{3}$. Stabla sa tanjim prečnikom od $30 \mathrm{~cm}$ učestvuju sa $51.5 \%$.

Ključne reči: šume bukve i jele, G4.61, održivo korišćenje, prirodni resursi

\section{INTRODUCTION}

Disappearance of forests by 10 million hectares per year points out to the gravity of the problem and necessitates urgent measures aimed at preventing degradation and devastation of existing forest ecosystems. In the concept of ecocentric (or biocentric) use of resources, the ecosystem represents a complexity of living organisms and has its value per se, as it considers human needs and relation to nature in a different way. A manner in which nature creates and maintains ecosystems is respected. The ecocentric concept protects, maintains and restores functioning of natural resources, at the same time exploiting, on lasting and permanent basis, all goods and services necessary for fulfilment of human needs. The preference is given to ecological processes in ecosystems, providing for the economic needs of the society, but not in a manner of industrial use. An integral part is consideration for soil, water, bio-diversity and biomass. Attainment of these goals is based on ecological, socio-demographic and economic criteria. The paper is based on the Concept of sustainable use and it is focused on smaller territorial units (areas)

\section{MATERIAL AND METHOD}

Habitat classification is based on EUNIS system of habitat classification. Habitat classification constitutes an integral part of EUNIS (European Nature Information System) system. This classification is created with a view to providing a universal, integral classification for European habitats (Lakušćić, D. et all., 2005; Ratknić, M., 2008). Species diversity of beech stands (floristic composition) was determined based on phytocenological records. The floristic composition was used for the analysis of life forms, spectra of floristic elements, preparation of ecological indices of communities, representation of medicinal herbs, fruit trees and melliferous species. Life forms, as indicators of stand conditions, were determined based on the representation of Phanerophyta, Chamephyta, Hemycryptophyta, Cryptophyta and Therophyta. Classification on basic types of life forms was conducted according to Raunkiaer (Diklić, N. 1984), based on characteristics for each species, given in Flora of Serbia I-X. Spectra of floristic elements were 
processed in conformity with the systematisation of plant-geographical elements by Gajić (Gajić, M. 1984), while the characteristics of each species were given in Flora of Serbia I -X. Ecological indices of communities were determined based on a biological spectrum of plants (Kojić, N. et al, 1997). Ecological indices for soil humidity, acidity, amount of nitrogen in soil (richness of mineral matter), according to light and temperature, were analysed. Medicinal plants were defined based on the data from the Strategy of medicinal plant protection in Serbia (Amidžić et al, 1999). Fruit tree types were defined based on the data from the book 'Wild fruit species of Serbia' (Mratinić, E, et Kojić, M., 1998). Melliferous species in beech stands were determined by drawing up a flora inventory. A number of melliferous species, the melliferousness degree and the average melliferousness of community were determined. Beech forest wood resources were determined based on the Specific forest-economic basis of the area.

\section{3, RESEARCH RESULTS}

According to EUNIS classification, analysed Pešter Plain forests belong to a mixed beech-fir forest type (G4.61). Beech-fir forests in the Pešter Plain occur only at three locations: at Gutavica- above the village of Ugla in Fakuf Zabran, in the Bare area and at Ogorijevac. Their low representation is a result of the sensitivity to browse and stamping. Fir is less preserved than spruce, and in small groups. It has not been preserved at positions exposed to wind, either. It survived only in inaccessible canyons and river cliffs in the Bare area. This forest does not exist as a complex, but it occurs alternately with other communities, in form of a mosaic. In degraded stands, a mass occurrence of aspen, and in some places aspen and birch tree, took place. The beech fir community at the Ogorijevac, Markovića Potok and Jasikovac locality is situated at the altitude between 1,100 and $1,350 \mathrm{~m}$. It occupies northern exposures at lower altitudes, while in western, south-western and north-western exposures, it is located at higher altitudes. In the area of Dubočica, the stands are located at inclinations of 20 to $45^{\circ}$ (in the Markovića Potok canyon). The soil in beech and fir forest at Ogorijevac is luvisol. At Jasikovac, distric cambisol is represented. The soil is acid, with $\mathrm{pH}$ value in water from 3.8 to 4.8 , while in $\mathrm{KCl}$ it is from 3.0 to 4.0.

65 plant species were identified in the community. There are 6 species in the tree storey, 9 shrub species in the second storey and only 50 species in the ground flora layer.

Community floristic composition in beech and fir forests: Abies alba Mill., Lapsanacommunis L., Acer pseudoplatanus L., Loniceranigra L., Aegopodium podagraria L., Luzula luzuloides (Lam.) Dan., Ajuga reptans L., Luzula pilosa (L.), Willd., Anemone nemorosa L., Melampyrum pratense L., Anemone ranunculoides L., Moehringia trinervia (L.) Clairv., Angelica sylvestris L., Mycelis muralis (L.) Rchb., Aremonia agrimonoides (L.) DC., Orchis pallens L., Asperula odorata L., Oxalis acetosella L., Athyrium filix-foemina (L.) Roth., Paris quadrifolia L., Betula pendula Roth., Pinus silvestris L., Brachypodium silvaticum (Huds.) P.B., Platanthera bifolia (L.) Rchb., Calamagrostis arundinacea (L.) Roth., Polygonatum verticillatum (L.) All., Campanula persicifolia L., Polypodium vulgare L., Carex hirta L., Polystichum aculeatum (L.) 
Roth., Carex silvatica Huds., Populus tremula L., Cephalanthera rubra (L.) Schr., Potentila erecta (L.) Raucsh., Corylus avelanna L., Prenanthes purpurea L., Crataegus monogyna Jacq., Ranunculus nemorosus DC., Dactylorhiza maculata (L.) Soo., Rosa pendulina L., Danaa cornubiensis (Torn.) Burn., Rosa vosagiaca Desp., Daphne laureola L., Rubus hirtus W.et K., Evonymus europaeus L., Solidago virga-aurea L., Fagus silvatica L., Sorbus aucuparia L., Festuca valesiaca Schl., Sorbus austriacus (Beck.) Hedl., Fragaria vesca L., Stachys silvatica L., Galium silvaticum L., Vaccinium myrtillis L., Gentiana asclepiadea L., Valeriana dentate, Glechoma hirsuta W.etK., Veratrum nigrum L, Hypericum maculatum Cr., Veronica officinalis L., Hypericum montanum L., Viola alba Bess., Knautia drymeia Hauff.

In the spectrum of life forms, lower presence of hemicryptophytes $(44.44 \%)$ can be observed in comparison to other communities in the area, which is a result of more favourable climatic conditions in the river Dubočica valley, where beech and fir community is mostly represented (Table 1). A high share of geophytes $(22.22 \%)$ points out to more favourable soil conditions (depth, humidity and structure), but also to a favourable relative air humidity, which is a result of rivers and streams flowing through stands. Phanerophytes and nano-phanerophytes account for $25.39 \%$. Chamaephytes account for $3.18 \%(1.59 \%$ of woody and herbaceous, respectively), therophytes account for $1.59 \%$, while therophytes/chamaephytes account for $3.17 \%$.

Table 1. Life forms spectrum in beech and fir forests

\begin{tabular}{|c|c|c|c|c|c|c|c|}
\hline \multicolumn{2}{|c|}{ life forms (\%) } \\
\hline Phanerophytes & $\begin{array}{c}\text { Nano- } \\
\text { phanerophytes }\end{array}$ & $\begin{array}{c}\text { Woody } \\
\text { chamaephytes }\end{array}$ & $\begin{array}{c}\text { Herbaceous } \\
\text { chamaephytes }\end{array}$ & $\begin{array}{c}\text { Hemicrypto } \\
\text { phytes }\end{array}$ & Geophytes & Therophytes & $\begin{array}{c}\text { Therophytes/ } \\
\text { chamaephytes }\end{array}$ \\
\hline $\mathrm{p}$ & $\mathrm{np}$ & $\mathrm{wc}$ & $\mathrm{hc}$ & $\mathrm{h}$ & $\mathrm{g}$ & $\mathrm{t}$ & $\mathrm{tc}$ \\
\hline 15.87 & 9.52 & 1.59 & 1.59 & 44.44 & 22.22 & 1.59 & 3.17 \\
\hline \multicolumn{2}{|c|}{3.18} & & 49 & \\
\hline
\end{tabular}

In the floristic elements spectrum, the Central-European floristic elements constitute the largest group in the community (38.10\%). Euro-Asian floristic elements account for $26.98 \%$, circumpolar-cosmopolitan account for $11.11 \%$, while sub-Mediterranean account for 7.94\%. Arctic-Boreal floristic elements account for $9.52 \%$, while Pontic-Central Asian constitute $4.76 \%$. Beech and fir forest belongs to a Central-European type of community, which is manifested through a dominant role of Central-European floristic elements (Table 2).

Table 2. Floristic elements spectrum in beech and fir forest

\begin{tabular}{|c|c|c|c|}
\hline Description of a floristic elements group & Floristic element & \multicolumn{2}{|c|}{ Share in \% } \\
\hline \multicolumn{4}{|c|}{ 1. FLORISTIC ELEMENTS OF NORTHERN REGIONS } \\
\hline \multicolumn{4}{|c|}{\begin{tabular}{|l|l|} 
Arctic floristic elements & \\
\end{tabular}} \\
\hline \multirow[t]{3}{*}{ Boreal floristic elements } & sub-Boreal & 1.59 & \multirow[b]{3}{*}{9.52} \\
\hline & sub-Boreal-European-west Siberian & 1.59 & \\
\hline & Sub-Boreal-Circumpolar & 6.35 & \\
\hline \multicolumn{4}{|c|}{ 2. CENTRAL-EUROPEAN FLORISTIC ELEMENTS } \\
\hline Central-European & Central-European & 17.46 & \multirow[b]{3}{*}{38.10} \\
\hline \multirow[t]{2}{*}{ European } & sub-Central-European & 19.05 & \\
\hline & Alpine-Carpathian & 1.59 & \\
\hline
\end{tabular}




\begin{tabular}{|c|c|c|c|}
\hline Description of a floristic elements group & Floristic element & \multicolumn{2}{|c|}{ Share in \% } \\
\hline sub-Atlantic and Atlantic & sub-Atlantic/ sub-Mediterranean & 1.59 & 1.59 \\
\hline \multicolumn{4}{|c|}{ 4. SUB-MEDITERRANEAN FLORISTIC ELEMENTS } \\
\hline sub-Mediterranean & sub-Mediterranean & 4.76 & \multirow[b]{3}{*}{7.94} \\
\hline eastern-sub-Mediterranean & eastern-sub-Mediterranean & 1.59 & \\
\hline $\begin{array}{l}\text { Balkan } \\
\text { Balkan-Apennine }\end{array}$ & sub-Illyrian & 1.59 & \\
\hline \multicolumn{4}{|c|}{ 5. PONTIC-CENTRAL ASIAN FLORISTIC ELEMENTS } \\
\hline \multirow[t]{3}{*}{ Pontic } & sub-Pontic & 1.59 & \multirow[b]{3}{*}{4.76} \\
\hline & Pontic-eastern-sub-Mediterranean & 1.59 & \\
\hline & sub-Pontic-sub-Mediterranean & 1.59 & \\
\hline \multicolumn{4}{|l|}{ 6. EURO-ASIAN FLORISTIC ELEMENTS } \\
\hline & sub-south-Siberian & 6.35 & \multirow[b]{3}{*}{26.98} \\
\hline & Euro-Asian & 14.29 & \\
\hline & sub-Euro-Asian & 6.35 & \\
\hline \multicolumn{4}{|c|}{ 7. CIRCUMPOLAR AND COSMOPOLITAN FLORISTIC ELEMENTS } \\
\hline & circumpolar & 4.76 & \multirow[b]{3}{*}{11.11} \\
\hline & sub-circumpolar & 3.17 & \\
\hline & cosmopolitan & 3.17 & \\
\hline
\end{tabular}

The community has a large canopy closure on the first story, ranging from 0.6 to 0.9 . The mean tree height is between 19 and $30 \mathrm{~m}$, while the mean diameter is from 30 to $35 \mathrm{~cm}$. In addition to fir (Abies alba) and beech (Fagusmoesiaca), there is a significant presence of birch tree (Betula pendula), aspen (Populustremula), maple (Acer pseudoplatanus) and white pine (Pinus silvestris). In the shrub storey, Abies alba, Fagus moesiaca and Corylus avellana dominate. There is a significant presence of Sorbus aucuparia and Evonymus europaeus, while Betula pendula, Crataegus monogyna, Daphne laureola, Lonicera nigra, Populus tremula, Rosa pendulina and other are less represented. In the third storey, a significant presence of Vaccinium myrtilus can be observed, which points out to frigoriphilic conditions for development of ground vegetation. There is also a significant presence of Anemone nemorosa, Aremonia agrimonioides, Glechoma hirsuta, Polygonatum verticillatum, Prenanthes purpurea, Athyrium filix-femina, Brachypodium silvaticum, Carex silvatica, Galium silvaticum, Gentiana asclepiadea, Platantera bifolia, Polysticum aculeatum and Solidago virga aurea.

\subsection{Beech and fir forest ecological indices}

Beech and fir forest ecological indices have the following average values: humidity (V) 2.96 (2.90 to 3.00): soil chemical reaction (K) 2.97 (2.71 to 3.15); nutrient matter $(\mathrm{N}) 2.69$ (2.55 to 2.65); light (S) 2.39 (2.28 to 2.60) and temperature (T) 2.84 (2.59 to 3.07$)$.

Table 3. Characteristics of beech and fir forest stands

\begin{tabular}{|c|l|l|c|c|c|}
\hline $\begin{array}{c}\text { Record } \\
\text { number }\end{array}$ & \multicolumn{1}{|c|}{ Geological substratum } & \multicolumn{1}{c|}{ Soil } & $\begin{array}{c}\text { Altitude } \\
(\mathrm{m})\end{array}$ & Exposure & Inclination $^{0}$ \\
\hline 1 & Diabase - hornstone & Eutric cambisol & 1300 & $\mathrm{~W}$ & 35 \\
\hline 2 & Gabbro-amphibolite & Eutric ranker & 1300 & $\mathrm{~W}-\mathrm{SW}$ & 20 \\
\hline 3 & Gabbro-amphibolite & $\begin{array}{l}\text { Distric } \\
\text { cambisol }\end{array}$ & 1280 & $\mathrm{~W}$ & 45 \\
\hline 4 & Quartz conglomerates and sandstone & Luvisol & 1140 & $\mathrm{~N}$ & 20 \\
\hline
\end{tabular}


Table 4. Beech and fir forest ecological indices

\begin{tabular}{|c|c|c|c|c|c|c|c|}
\hline $\begin{array}{c}\text { Record } \\
\text { number }\end{array}$ & $\begin{array}{c}\text { Heat } \\
\text { coordinate }\end{array}$ & Stand & $\mathrm{V}$ & $\mathrm{K}$ & $\mathrm{N}$ & $\mathrm{S}$ & $\mathrm{T}$ \\
\hline 1 & 6 & 0.9 & 2.97 & 3.15 & 2.76 & 2.41 & 2.96 \\
\hline 2 & 7 & 0.6 & 2.90 & 3.07 & 2.65 & 2.60 & 3.07 \\
\hline 3 & 6 & 0.8 & 3.00 & 2.71 & 2.55 & 2.28 & 2.59 \\
\hline 4 & 5 & 0.9 & 2.97 & 2.95 & 2.83 & 2.25 & 2.73 \\
\hline
\end{tabular}

Medicinal plants in beech and fir forests. The presence of 63 plant species was identified in beech and fir forests, out of which 29 , that is, $46 \%$ are medicinal. Within the healing class one 4 species were identified, within the healing class two 2 species, within the healing class three 11 species, within the healing class four 6 species and within the healing class five 6 species. The following species come under the healing class one: Vaccinium myrtillis L., Platanthera bifolia (L.) Rchb., Betula pendula Roth. and Crataegus monogyna Jacq.; under the healing class two: Solidago virga-aurea L. and Veronica officinalis L.; under the healing class three: Potentila erecta (L.) Raucsh., Veratrum nigrum L., Glechoma hirsuta W.etK., Gentiana asclepiadea L., Abies alba Mill., Fagus silvatica L., Polypodium vulgare L., Asperula odorata L., Populus tremula L., Evonymus europaeus L. and Ajuga reptans L. The species that came under the healing class four are the following: Oxalis acetosella L., Angelica sylvestris L., Fragaria vesca L., Acer pseudoplatanus L., Corylus avelanna L. and Sorbus aucuparia L., while the species under the healing class five are: Anemone nemorosa L., Aegopodium podagraria L., Daphne laureola L., Paris quadrifolia L., Pinus silvestris L. and Lapsana communis L.

Fruit trees in beech and fir forests. The following fruit tree species were identified: Vaccinium myrtillis, Crataegus monogyna, Fragaria vesca, Sorbus aucuparia, Lonicera nigra, Rubus hirtus, Sorbus austriacus.

Melliferous species in beech and fir forests. Based on the conducted analysis, 24 melliferous species were identified in the beech and fir forest, out of which 8 woody, 6 shrub and 10 herbaceous. The mean melliferousness of the community amounts to 2.66. The following woody species are represented: Populus tremula L., Sorbus aucuparia L., Sorbus austriacus (Beck.) Hedl., Betula pendula Roth., Abies alba Mill., Fagus silvatica L., Acer pseudoplatanus L. i Pinus silvestris L. The following woody species are identified: Corylus avelanna L., Rosa pendulina L., Crataegus monogyna Jacq., Evonymus europaeus L., Vaccinium myrtillis L. i Daphne laureola L.; the following herbaceous species are identified: Anemone nemorosa L., Campanula persicifolia L., Stachys silvatica L., Solidago virga-aurea L., Gentiana asclepiadea L., Ajuga reptans L., Fragaria vesca L., Angelica sylvestris L., Aegopodium podagraria L. and Anemone ranunculoides $\mathrm{L}$.

The highest number of melliferous plants blossom in May.

\subsection{Beech and fir forest wood resources}

The beech and fir forest was recorded on 464.09 hectares (Table 5). The total volume is $161,015 \mathrm{~m}^{3}$. Trees with diameters lower than $30 \mathrm{~cm}$ account for $51.5 \%$. 
Table 5. Beech and fir forest wood resources

\begin{tabular}{|c|c|c|c|c|c|c|c|c|c|c|}
\hline $\begin{array}{c}\text { Surface } \\
\text { area } \\
(\mathrm{ha})\end{array}$ & $\begin{array}{c}\text { Total } \\
\text { volume } \\
\left(\mathrm{m}^{3}\right)\end{array}$ & \multicolumn{6}{|c|}{ Volume according to diameter classes } & $\begin{array}{c}\text { Volume } \\
\text { increment } \\
\left(\mathrm{m}^{3}\right)\end{array}$ \\
\hline 464.09 & 161015 & 245 & 35049 & 41595 & 43054 & 24054 & 7625 & 2639 & 344 & 3947 \\
\hline
\end{tabular}

\subsection{Ecological characteristics of pyramidal fir at Ogorijevac}

Common fir (Abies alba Mil1.) shows less variety in comparison to other conifers. According to habitus, three groups of variety can be distinguished: (1) pyramidal, pillar-shaped, conical (2) hanging or weeping (3) dwarfish. Until present, the pyramidal variety has been found only in three areas in Europe, in form of individual trees. A finding site of pyramidal fir is at the Ogorijevac locality, near the village of Kladnica in the vicinity of Sjenica. The key characteristic is a pyramidal habitus, created in a morphogenesis process during the course of development and growth. The pyramidal habitus, which occurs within many species of different systematic tree groups, is created in different ways. In pyramidal fir, that habitus property originates from twig characteristics. A comparative analysis of common and pyramidal fir twig and needle characteristics points out to common and differential properties. On these grounds, the basis for further studies of genetic, ontogenetic and physiological-ecological processes, which lead to occurrence of different habitus, can be established.

A variety of pyramidal fir forms a mixed uneven-aged stand jointly with a common fir and beech. Unlike other finding sites in Europe, in which individual trees have been recorded, a total of 7 older specimen of this variety, of various age, have been identified in this locality. Among numerous specimen of young growth, there are those which will form a pyramidal habitus. Pyramidal firs crossbreed with common fir. The majority of pyramidal and common fir offspring possess characteristics of common fir. In one part of the offspring, a sharper angle of branches in relation to stem growth, can be observed.

Pyramidal fir is a tree of first class and attains the same heights as common fir. It is difficult to visually determine its age, due to numerous branches, positioned under a very sharp angle in relation to a stem spindle, particularly near the top, where branches almost cling to a stem. The habitus is narrow-pyramidal or conical, with a very sharp top, similar to that of cypress. Branches are very thick and, since the earliest youth, positioned under a very sharp angle in relation to stem spindle (about $20-30^{\circ}$ ). Apart from whorls, they also occur in internodes. In pyramidal fir, a disposal of lower branches also occurs in a dense forest canopy, although dry branches remain on the stem for a long time.

The pyramidal fir's top is without a distinct terminal shoot. In adult trees, it is elongated and cylinder-shaped, with numerous lateral twigs stretched upwards and nearly clinging to the central shoot. In youth, the top is particularly sharp, due to a higher height increment.

Pyramidal fir has a very distinct vertical tendency. Its habitus bears similarities to cypress and juniper, but also have common characteristics with closer relatives, fir and spruce. 
Table 6. Morphological characteristics of common and pyramidal fir

\begin{tabular}{|l|l|}
\hline \multicolumn{1}{|c|}{ Common fir } & \multicolumn{1}{c|}{ Pyramidal fir } \\
\hline Habitus broad conical & Habitus narrow pyramidal \\
\hline Oval top & Sharp top \\
\hline Branching always horizontal & Branching always upward, with a vertical tendency \\
\hline Needles horizontally spread in two rows & Needles pointed radially and upward, along the whole twig \\
\hline $\begin{array}{l}\text { Needle at cross-section flattened with a receding } \\
\text { central nerve }\end{array}$ & $\begin{array}{l}\text { Needle at cross-section elliptical with a convex central } \\
\text { nerve }\end{array}$ \\
\hline Seed wings are wide and fan-shaped & Seed wings are narrow and elongated \\
\hline
\end{tabular}

\section{DISCUSSION}

The adverse impact of climate changes on forest eco-systems will be particularly apparent through occurrence of extreme atmospheric phenomena, such as drought, storms, extremely high temperatures, intense erosion processes and occurrence of plant diseases and pests. Serbia is territorially situated in a region with the highest frequency of drought occurrence. An increase of vegetation period is expected. The increase of mean air temperature will cause a shift of climatic and, consequently, vegetation zones toward poles and in terms of altitude. A climate change of $1^{0} \mathrm{C}$ will cause a vegetation shift toward north for $200-300 \mathrm{~km}$, along with a shift toward higher altitudes of 150-200 m. Global warming will cause vegetation shift toward poles and higher altitudes, along with a change of vegetation structure. A tree (forest) dieback will increase due to inadequate ecological conditions of habitats and an increase of entomological and phytopathological diseases. Climate change will cause changes in the growth rate of certain species, hamper natural regeneration, owing to change of habitat humidity. An increased occurrence of forest fires and atmospheric disasters is also expected.

Climate changes will cause changes in natural eco-systems, not only in terms of their dislocation, but in terms of their structure. A biological potential for adaptation will be reduced and diversity limited. The most endangered are the communities and species with limited adaptation potentials. The most serious problem in adaptation of forest and shrub communities to climate changes is the rate of the change. Changes in natural eco-systems can threaten preservation of rural values. It is considered that application of adequate measures in forest ecosystem management can reduce ecological and social-economic effects of deterioration of forests.

The expected effects of climate changes with respect to forest eco-systems, forest communities and tree, shrub and ground flora species, are the following;

- shifting of boundaries of certain forest types with respect to geographic latitude and altitude;

- different natural redistribution of forest type areas with respect to geographic latitude and altitude;

- probably, considered in long term, 'losing the battle' on part of certain communities and their 'giving up' the race and being driven out (extinction);

- different composition of certain plant communities, followed by disappearance of one and occurrence of other species in relation to their 
storey and social position;

- change of relation of certain tree species toward light;

- forest communities will be more exposed to various adverse impacts, which are direct or indirect result of climate changes; It should be noted that relict, rare and endangered forest communities and their basic, distinctive tree types, bear a higher degree of risk from the expected negative effects.

- The above mentioned effects, considered cumulatively, will be directly reflected in the potential for preservation of biological diversity and possibility for rational management of these resources.

The above-mentioned effects directly influence the possibility and intensity of planning of sustainable forest management.

\section{CONCLUSION}

Given that a centuries-long destruction of plant resources in the area of Pešter Plain has endangered their condition, that also directly concerns a sociodemographic status of population. The aim of these studies is to define the condition of natural resources, determine priority activities aimed at prevention of adverse impact and to determine measures for improvement of condition. By attaining the aims of the study of sustainable use of Pešter Plain plant resources, the basis are created for: implementation of European standards and models and preparation of methodology for recording of renewable plant resources; creation of strategic framework for sustainable management of renewable resources, based on principles of sustainable development and previous level of exploration of existing natural resources; maintenance and increase of ecological, biological, climatic, social-cultural and economic benefits derived from the use of plant resources; protection of environmental, social and spiritual function and values of natural ecosystems, attained by establishment, increase and adequate management of protected areas and communities; preservation of forests in representative ecological systems and areas; preservation and management of wild game; preservation of genofund; measures aimed at providing support and ensuring sustainable use of biological resources and preservation of bio-diversity; support and improvement of national programmes for afforestation and re-cultivation of degraded habitats, establishment and improvement of existing forests of various uses, in order to reduce the pressure on existing forest eco-systems; basing the concept of planning of permanent management of renewable plant resources on a criterion - preservation of environment quality, which means that economic use of renewable plant resources must not reduce numerous ecological functions, while maintaining and enriching biodiversity of habitats; creation of conditions for establishment of elements of sustainable agricultural production; preservation and improvement of bio-diversity.

The collected data enable performance of a multi-layered comparative analysis of space by GIS technology, along with determining the degree of endangerment of natural resources. Foreseeing direct and indirect effects of excessive use of resources has been facilitated. 
A number of interactively related sub-programme activities can be formulated in several general programme tasks: environment protection, optimum use of natural resources, strengthening of secondary activities, marketing analyses and analyses of commercial offering of this area, strictly in line with preservation of natural resources and environment protection (by application of principles of sustainable development of renewable plant resources).

\section{Acknowledgement}

This paper was realized as a part of the project "Studying climate change and its influence on the environment: impacts, adaptation and mitigation" (43007) financed by the Ministry of Education and Science of the Republic of Serbia within the framework of integrated and interdisciplinary research for the period 20112014.

\section{REFERENCE}

Amidzić, L., Dražić, S., Kostić, M., Maksimović, S., Mandić, R., Menković, N., Panković, B., Popov, V., Radanović, D., Roki, Đ., Sekulović, D., Stepanović, B., Tasić, S. (1999): Strategija zaštite lekovitog bilja u Srbiji, Ministarstvo zaštite životne sredine Republike Srbije, Beograd.

Diklić, N. (1984): Životne forme biljnih vrsta и biloški spektar flore SR Srbije, Vegetacija SR Srbije I, Srpska Akademija Nauka i Umetnosti, Beograd.

Gajić, M. (1984): Florni elementi SR Srbije,Vegetacija SR Srbije I, Srpska Akademija Nauka i Umetnosti, Beograd.

Kojić, M., Popović, R., Karadzić, D.(1994): Fitoindikatori i njihov značaj u proceni ekoloških uslova staništa, Institut za istraživanja u poljoprivredi “ Srbija “, Beograd.

Lakušić, D., Blaženčić, J., Ranđelović, V., Butorac, B., Vukojčić, S.,Zlatković, B.,Jovanović, S., Šinžar-Sekulić, J., Žukovec,D., Ćalić, I., Pavićević, D.(2005):Staništa Srbije-Priručnik sa opisima i osnovnim podacima.-In:Lakušić.D. (ed.): Staništa Srbije, Rezultati projekta "Harmonizacija nacionalne nomenklature u klasifikaciju staništa standardima međunarodne zajednice"Institut za botaničku i Botanička Bašta "Jevremovac", Biološki fakultet, Univerzitet u Beogradu, Ministarstvo za nauku i zaštitu životne sredine Republike Srbije.

Mratinić, E., Kojić, M.(1998): Samonikle vrste voćaka Srbije, Institut Srbija, Beograd.

Ratknić, M. (2008): Razvoj kapaciteta privatnog sektora za održivo gazdovanje šumama u Srbiji - Budovanie kapacit sukromneho sektora pre trvalo udržatelne obhospodarovanie lesov v Srbskej Republike, Slovak Aid, National forest Centre Zvolen - Slovak Republik, Institut za šumarstvo, Beograd. 